7. Black spots conspicuous, arranged in transverse rows; black specks not always conspicuous. (N. Y., Mass.; also collected by Fletcher in Canada, on Quercus rubra.) . . . . . . . . pettiti Ehrh. Black spots minute, not definitely arranged in transverse rows; black specks very distinct; ground color pale ochreous. (Calif., Mexicn.)

nigropunctatus Ehrh. \& Ckll.

I have taken as typical of galliformis a specimen from the Riley collection, collected by J. H. Mellichamp at Bluftion, S. C. Riley's description shows that he also included $K$. pettiti under the same name. Mr. G. B. King has collected petiti in Massachusetts

\title{
THE SPECIES OF THE OEDIPODINE GENUS HELIASTUS SAUSS., OCCURRING IN THE UNITED STATES.
}

BY SAMUEL H. SCUDDER, CAMBRIDGE, MASS.

Heliastus was founded by Saussure in I 884 on some Mexican and Central American Oedipodinae. It was first recognized as occurring in the United States three years ago, when I referred to it two insects which had been described as species of Thrincus. Both of these species also occur in Mexico, but were unknown to Saussure. I can now add another and undescribed species, known to me from only a single locality in California, and collected by Mr. A. P. Morse. All these northern species belong to Saussure's second division of the group in which the lower posterior angle of the lateral lobes is not produced into a distinct process. They are all of a light gray color, more or less irregularly spotted with brown, sometimes forming brief transverse markings when the insect is alighted; the wings are glazed, often iridescent, and generally, at least in part, weakly tinted. The males are considerably smaller than the females. The species may be separated as follows : -

\section{Table of our species of Heliastus.}

$a^{1}$. Of large size. Antennae at least two thirds as long as hind femora; posterior process of metazona weakly obtusangulate, often almost rectangulate; descending lobes of pronotum apically well rounded, falling distinctly below the level of the pleural lobe anterior to them.

$b^{1}$. Larger. Descending lobes of pronotum angulato-rotundate below; wings hyalino-citron basally, weakly infuscated apically . • aridus. $b^{2}$. Smaller. Descending lobes of pronotum regularly rotundate below ; wings pellucid, or faintly violaceous, only the veins fuscous.

californicus. $a^{2}$. Of small size. Antennae only half as long as hind femora; posterior pro- 
cess of metazona strongly obtusangulated, or broadly rounded; descending lobes of pronotum apically truncate, not falling below the level of the free pleural lobe anterior to them.

minimus.

\section{Heliastus aridus.}

Thrincus aridus Brun., Proc. U. S. nat. mus., xii, 78-79. pl. I, fig. 2, 3 (aridus on plate; avidus in text) (1 890$)$; Ril., N. A. fauna, vii, $25^{2}$ (1893); Towns., Ins. life, vi, 3 I (1893).

Heliastus aridus Scudd., Can. ent., xxix, 75 (1897); Catal. Orth. U. S. 44 ( r 900 ).

Originally described from Albuquerque, N. Mex. (Bruner), it has since been recorded from Las Cruces, N. Mex. (Townsend), and Panamint Valley, Cal. (Riley). I have received it from Las Cruces (Townsend) and Mesilla, N. Mex., July I (Morse), as well as from Juarez, Mex., July 3 (Morse). Mr. Morse tells me that it is a common insect at Mesilla, found on sand hills and the gravelly mesa, where it is almost invisible, the color and markings varying with the locality; it flies freely, but not far.

\section{Heliastus californicus.}

Thrincus californicus Thom., Bull. U. S. geol. surv. terr., i, no. 2, ser. i, 66 (I874) ; Glov. I1l. N. A ent., Orth., pl. I7, fig. 6, 7 (1874); Coq., Ins. life, i, 228 (1889) ; Brun., Proc. U. S. nat. mus. xii, I 87 ( I 890).

Heliastus californicus Scudd., Can. ent. xxxix, 75 (1897); Cit. Orth. U. S., 44 (1900).

This species was described by Thomas from specimens taken by Crotch in Southern California, and has since been mentioned as found at Los Angeles, Cal. (Coquillett), and in the Cerros Isl. off the coast of Lower California (Bruner). I have seen specimens from San Diego (Crotch), Indio, July 9 (Morse), Palm Springs, July 9 (Morse), Mohave, Cal., Aug. I (Morse), and Rock Spring in southeastern California (Palmer), as well as from some other unspecified point in California, collected by Osten Sacken,* who reports it as found "among boulders of granite, the colors of which it seems to mimic." I have it also from St. George, Utah, Apr. r-I 2 (Palmer), from Saltillo, Mex., Mar. 2I-28 (Palmer), and Sonora (Schott), as well as from Cape St. Lucas, Lower California (Xantus).

\section{Heliastus minimus sp. nov.}

Uf small size, cinereo-testaceous, more or less embrowned above on head and pronotum, marked with brownish fuscous, the face, genae, lower portion of lateral lobes and sometimes their whole metazonal portion overlaid with chalky white. Head prominent, the sculpturing much as in $H$. californicus but the face retreating more; eyes rather prominent, especially in male; antennae short, about half as long as the hind femora, in no way attenuate or depressed at apex, fusco-testaceous, feebly in-

* Baron Osten Sacken collected Orthoptera in Sonoma and Marin Cos. north of San Francisco, but this insect has not otherwise been reported from so northern a locality, or farther north than Mohave. 
fuscated apically, not banded. Pronotum marked with brownish fuscous on the prozona behind the eyes and sometimes across the posterior margin of the prozonal disk, the front margin of which is a little elevated especially above and in the male, the disk of whole prozona tolerably smooth and nearly plane, the median carina very slight, the hind margin strongly obtusangulate or broadly rounded, the lateral lobes inferiorly truncate not extending below the level of the free pleural lobe. Tegmina rather slender, subequal, pale testaceous, feebly embrowned mesially in proximal half, flecked conspicuously with well distributed brownish fuscous spots; wings glistening hyaline, a few of the veins at extreme apex narrowly and inconspicuously infuscated, at least in the female. Hind femora long and slender,

\section{INSECT-NEURATION.}

The work of Comstock and Needham* upon the wings of insects is decidedly an important contribution to the subject, for a firm step has been taken towards a satisfactory theory of venation. This advance has been attained by an extended study of the tracheae which precede and, in a broad way, determine the positions of the veins. Selecting immature stages of generalized representatives of each order, the authors arrive at a type of tracheation which may fairly be taken to represent a primitive condition,an origin for more complicated types of tracheation and venation. The lines along which specialization appears to have occurred in the larger orders are carefully traced and the processes fully and clearly figured. Specialization occurs either by the reduction (atrophy or coalescence) or else by the addi-

\footnotetext{
* Comstock, J. H. and Needham, J. G. The Wings of Insects. A series of articles on the structure and development of the wings of insects, with special reference to the taxonomic value of the characters presented by the wings. 124 pp., go figs. Reprinted from The American Naturalist. Ithaca, N. Y. The Comstock Publishing Co.
}

pale testaceous, occasionally and especially at base hoary, bifasciate above with brownish fuscous.

Length of body, $\delta, 10.25 \mathrm{~mm} ., \quad+, 18$ $\mathrm{mm}$; antennae, $\delta, 3.5 \mathrm{~mm}$., $q, 5 \mathrm{~mm}$.; tegmina, $\delta, 9.5 \mathrm{~mm}$., + , $16.5 \mathrm{~mm}$.; hind femora, $\delta, 7 \mathrm{~mm}$., $q$, I $\mathrm{mm}$. One male is of unusual size, the tegmina measuring $\mathrm{r} 4$ $\mathrm{mm}$. in length, but otherwise there is little variation in the specimens from the above figures.

\section{I3 of I3 + . Palm Springs, Cal.,} July 9, I 2, A. P. Morse.

The species is peculiar for its small size, short antennae, slender hind femora, brief lateral lobes and broadly angulate metazonal process.

tion of veins from a multiplication of the branches of the principal veins. Fortunately the familiar terms adopted by Redtenbacher are retained.

Committing ourselves to the authors' conclusions, perhaps too unreservedly, we were mildly shocked to find that the method fails of application among Trichoptera, most Diptera and the Hymenoptera, at least, because the correlation between tracheae and veins is almost lost. As the method seems to have justified itself, however, a critic can scarcely do more at present than to emphasize the necessity of caution in the employment of the method.

Especially instructive are the discussions upon the wings of Odonata, Ephemerida and Orthoptera. The elytra of Coleoptera are definitely homologized with wings.

The palaeontological evidence is rather summarily dismissed with the negative conclusion that it does not contradict the authors' results. Precisely on account of the "imperfection of the record" does the close resemblance of the Devonian Xenoneura to the hypothetical type of the authors acquire a value that makes the above conclusion unnecessarily cautious. 

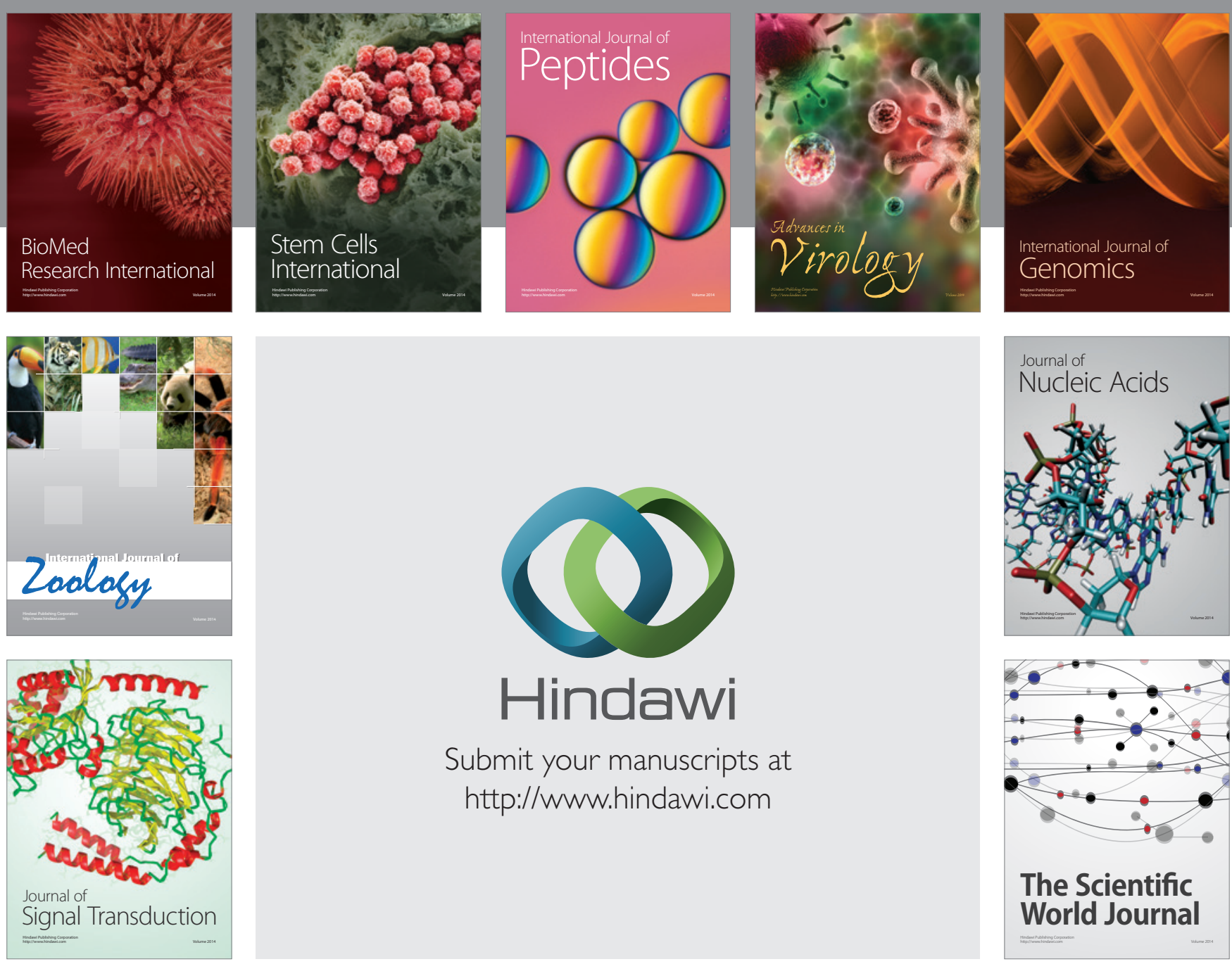

Submit your manuscripts at

http://www.hindawi.com
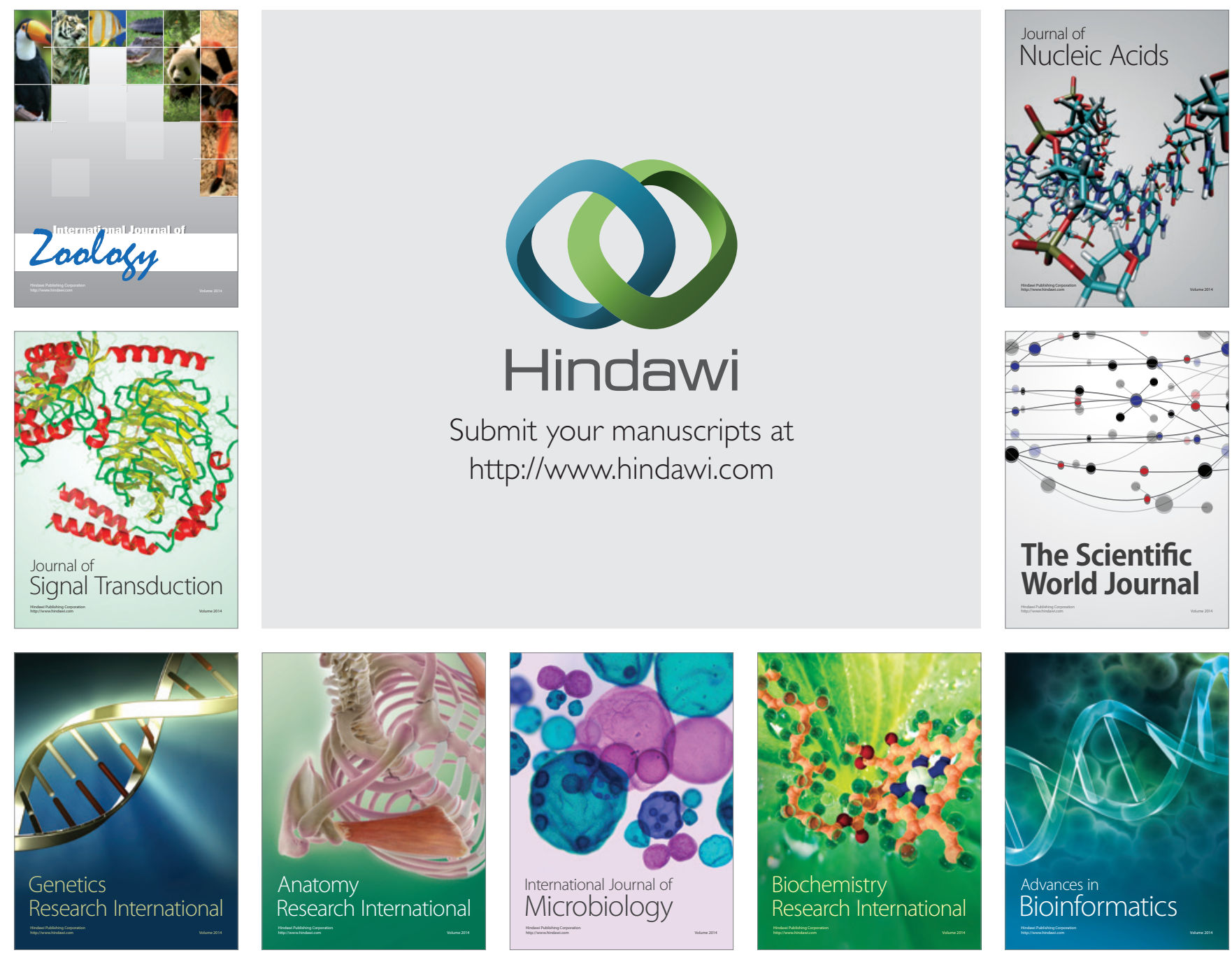

The Scientific World Journal
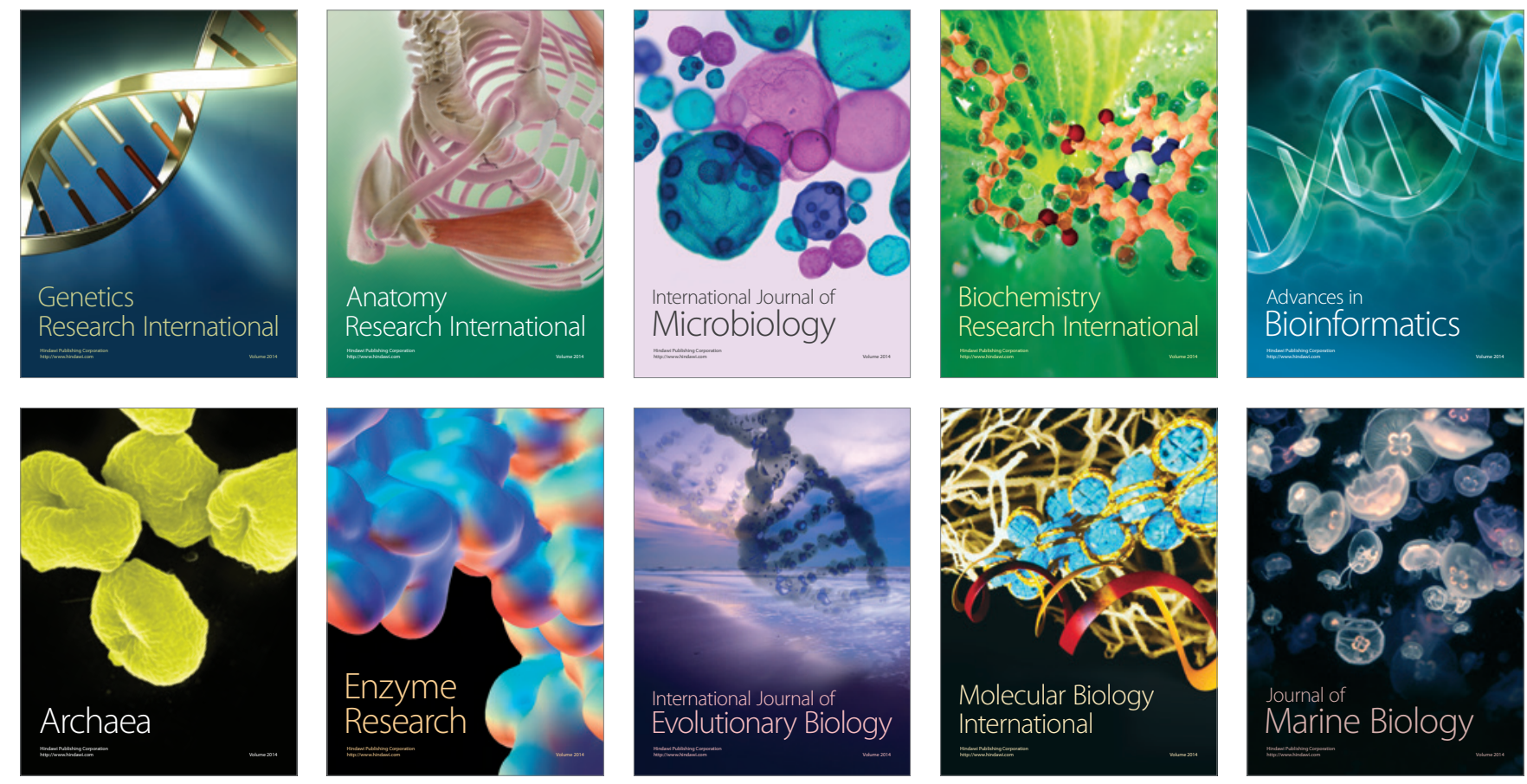